\title{
Circular Economy and its Prospects in Nepalese Agriculture
}

\author{
Santosh Kumar Bhattarai ${ }^{1, a, *}$, Suman Bhattarai ${ }^{1, b}$, Chandan KC ${ }^{1, c}$, Arun GC ${ }^{2, d}$ \\ ${ }^{1}$ Department of Agricultural economics, Institute of Agriculture and Animal Science (IAAS), Tribhuvan University, Nepal \\ ${ }^{2}$ Ministry of Agriculture and Livestock Development, Government of Nepal, Nepal \\ *Corresponding author
}

A R T I C L I N F O A B S T R A C T

Review Article

'Circular economy' in agriculture centres on the production of agricultural commodities using a minimal amount of external inputs, closing nutrient loops and reducing negative discharges to the environment (in the form of wastes and emissions). This can be achieved through the (re)design of maintenance, repair, reuse, remanufacturing, refurbishing, and recycling. Under the principles of

Received : 03/06/2020

Accepted : 22/11/2020 $\mathrm{CE}$, products and materials approaching their end-of-life stage can be regenerated or restored or replaced. Circular agriculture is aimed at closing the loop of materials and substances, and reducing both resource use and discharges into the environment. New measures like environmental taxes, insurance for liability resulting from environmental damage, cap and trade system and environmental labelling can be explored to promote transition of a current linear model to a circular one. The circular economy in Nepal is in infant stage and there is plenty of works to be done in this

Keywords:

Agriculture Circular economy

Environment protection sector. The results of the paper will be instrumental for the transition of Nepalese agricultural sector

Nepal

Sustainability

Wastes

to a more circular one.

skbhattarai99@gmail.com (iD) https://orcid.org/0000-0002-6826-6724

kcchandan01@gmail.com

iD https://orcid.org/0000-0002-6980-4539

sbhattarai867@gmail.com gcarun8848@gmail.com

(iD https://orcid.org/0000-0003-0620-8040 (D) https://orcid.org/0000-0002-2548-5177

(c) (1) (9) This work is licensed under Creative Commons Attribution 4.0 International License

\section{Introduction}

Agriculture is a critical sector of the Nepalese economy, providing the food, feed, and bio-resources that help to sustain society. The agriculture sector contributed about 27.6\% in the national GDP in FY 2017/18 (Ministry of Finance, 2018). The supply of chemical fertilizer in Nepal in the year $2016 / 17$ was $3,24,977$ metric tons (46.4\%) despite the potential demand of 7,00,000 metric tons and average subsidy since $2008 / 09$ is estimated to be NRs. 3,73,42,27,780 (43.78\%) (Panta, 2018). Getting obsessed with the chemical fertilizers, government of Nepal has allocated around $26 \%$ of the total agricultural budget for the subsidy of imported chemical fertilizers (Ministry of Finance, 2020). Nepal has spent a large amount of money on importing fertilizers and providing subsidy for using chemical fertilizers but still, we are not food secure. High dependence on neighboring countries for inputs like chemical fertilizers and pesticides shows how fragile is our food system. If the supply chain is disrupted for any political reason or as for the recent COVID-19 lockdown, it causes massive food insecurity in the regions. So, it becomes apparent to make our agricultural system more resilient to external shocks. The trade deficit in agriculture is widening. Production of nitrogen fertilizers is highly energy-intensive and generates a lot of greenhouse gases. In the last few years, agriculture has become more resource-intensive; relying heavily on the availability of fossil inputs in the form of synthetic nitrogen and phosphorus fertilizers, oil derived agrochemicals and fossil fuels. The financial return of current agricultural production systems could not end the rural poverty nor will it maintain the health of the ecosystem. If humanity continues in its current patterns of production and consumption, society will face a twin environmental crisis of resource scarcity and waste overload soon (Velenturf and Purnell, 2017). The fast-growing population is demanding a better life and a better environment to live in, thus pressing the need for sustainable development. In the last few years, the concept of a Circular Economy has gained relevance on a global scale for its capacity of shifting the current extractive linear economical model to more sustainable. 
The circular economy comes at the rescue to address environmental issue simultaneously with economic development. By circular, an economy is envisaged as having no net effect on the environment; rather it restores any damage done in resource acquisition while ensuring little waste is generated throughout the process. Circular economy (CE) is known as a "closed-loop" economy, in which the industries aim for a regenerative system in which waste and input energy are minimized (Kyriakopoulos et al., 2019). A circular economy is based on the principles of designing out waste and pollution, keeping products and materials in use, and regenerating natural systems (Ellen MacArthur Foundation, 2017).

So the circular economy says:

- Waste becomes a resource.

- Products are designed to be reused and recycled.

- Non-renewable natural resources are replaced by renewable.

- $\quad$ Energy is produced by renewable energy sources.

- People and industry are sharing items and services instead of ownership

- The general objective of this study is to assess the concept of circular economy and its prospects in Nepalese agriculture. The specific objectives of the study are:

- Assessing the opportunities of circular economy in Nepalese agriculture

- Linking circular agricultural approaches to global challenges

\section{Materials and Methods}

To get more in-depth knowledge of the prospects of the circular economy within the agricultural sector, various literature was consulted. The review is based on the information available from various literature, reports, internet and textbooks. Relevant scholarly journals and review articles were consulted using keywords (i.e., circular economy, sustainability, circular agriculture).

\section{Result and Discussion}

The national statistics illustrate that more than half of the cultivated area in Nepal is irrigated, but in actuality, only one-third of the area (36 per cent) has year-round irrigation facilities (MoAD, 2015). Furthermore, in recent years agricultural areas are also declining as a result of a conversion of prime agricultural land into non-agricultural uses (e.g., housing, industries and infrastructure development) through rapid urbanization and rural-urban migration (Gauchan, 2015). Currently, public sector is still a major player for agricultural research (new seed of varieties, source seeds, fertilizer), extension and provision of support services (subsidies, input supply etc.) both in accessible areas and remote regions, while private sectors are emerging in the provision of input supply and agroadvisory services connected to their agricultural inputs particularly in commercial production systems and market accessible areas (Gauchan, 2015).

Nepal is in primitive phases with most focus on the aspects of solid waste management. In September 2019, a dialogue was organized by Nepal Economic Forum to discuss the ways to mainstream circular economy into the economy of Nepal (NEF, 2019). The program has emphasized for initiation of the circular economy in Nepal through adaptation of the $3 \mathrm{R}$ (Reduce, Reuse and Recycle) principle at the beginning and recommended to explore additional opportunities for closing the loop (NEF, 2019). Though circular economies are applicable to various aspects of the economy, the program solely discussed the aspects of solid waste management. It is essential to create awareness for the adaptation of the circularity in the business (NEF, 2019) and motivate them to adopt innovative business models (Parajuly, 2019).

A growing literature indicates that the linear economic model is still the common practice in most countries (Secco et al. 2020; Junjie et al. 2011). Transition from the linear to the circular economy requires the overhaul change in all aspects of the economy including the product itself, production process and organizational process (Frodermann, 2018).

The circular economy implies there is no waste and in which material flows are of two types: biological nutrients, designed to re-enter the biosphere safely, and technical nutrients, which are designed to circulate at high quality in the production system without entering the biosphere as well as being restorative and regenerative by design (Oldfield et al., 2016). Thus, the circular economy focuses on reusing raw materials and preventing waste and harmful emissions to the environment wherever possible. In contrast, a linear economy operates on a take-makedispose model, using resources to produce products that will be discarded after use.
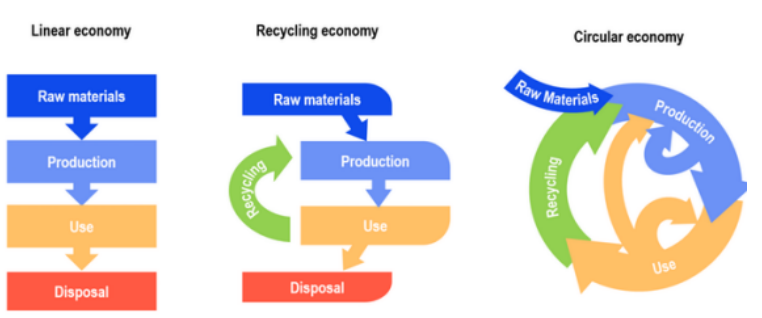

Figure 1. Linear, recycling and circular economies Source: Netherlands Government-wide Programme for a Circular Economy

'Circular economy' in agriculture centers on the production of agricultural commodities using a minimal amount of external inputs, closing nutrient loops and reducing negative discharges to the environment (in the form of wastes and emissions). The circular economy should design out waste from the beginning, rather than relying solely on waste recycling at the end of the chain. So, understanding the whole supply chain on how these parts or components influence one another within a whole economy is crucial.

As a large part of the national GDP is shared by agriculture in Nepal and other underdeveloped nations, the circular economy in the agriculture sector seems relevant as an entry point for a journey to sustainability. Circular agriculture is an ecological concept that is based on the principle of optimizing the use of all biomass. Circular agriculture is aimed at closing the loop of materials and substances, and reducing both resource use and discharges into the environment. Similarly, a circular economy in a 
food system implies reducing the amount of waste generated through the re-use of food, utilization of byproducts and food waste, and nutrient recycling by farmers and processors.

Today's agriculture system is mainly linear in structure, utilizing quite high levels of inputs, a large proportion of which is not converted into edible products but instead results in wasteful and environmentally damaging outputs. Some of the challenges possessed by the linear model are given below:

\section{Fluctuating Raw Material Prices}

The linear economy assumes a constant supply of natural resources. We may not run out of the resources but we have exhausted the easy to access reserves. It is having a significant impact on prices, and the century of commodity price declines enjoyed between 1900 and 2000 was effectively erased in the first decade of this millennium (Ellen MacArthur Foundation, 2013). This not only creates problems for diggers and buyers of raw materials but it also creates greater risks in the market. The number of people who suffer from hunger has slowly progressed over the past three years, with about one in every nine people globally suffering from hunger today (FAO, IFAD and WFP, 2015). And the major reason for the increase in hunger is attributed to an increase in the food price.

\section{Critical Materials}

Some inputs like Phosphorus (P) is one of the critical natural resources required for growing food; it is both scare and polluting our ecosystems. Exploitable reserves of phosphate rock are held in only a few countries, so geopolitical or market disruptions could threaten food security in regions that rely solely on Phosphorus imports (Cordell and White, 2014).

Using a comprehensive life-cycle analysis, Tonini et. al. (2019) examined externalities and net costs of $\mathrm{P}$ recovery technologies and they found that the internal production costs of $\mathrm{P}$ recovery were outweighed by the external impact costs of the environmental emissions (metals, particulate matter, greenhouse gases, and nutrients) caused by current $\mathrm{P}$ mining and bio-resource management. Overall, they concluded that it was more beneficial to society to use recovered $\mathrm{P}$ where the health and environmental impacts were more negative (Tonini et al., 2019). The authors estimated that recovered $\mathrm{P}$ products might substitute $17-31 \%$ of the rock phosphate-based $\mathrm{P}$ fertilizers used in Europe by 2030.

\section{Increase in Material Demand}

Because of population growth, a significant increase in demand for materials is predicted despite a limited supply of raw materials. Product lifespan is decreasing because there is a process of positive feedback: consumers want new products faster and therefore use their old product shorter which encourages the use of less quality raw materials which in turn leads to consumers wanting new products even faster.

The System is Inefficient and Contributes to Environmental Degradation

Industrialized farming practices cost the environment USD 2.6 trillion per year in negative environmental externalities and many agricultural industries would be unprofitable if externalities like land degradation, biodiversity loss, GHG emission, adverse health effects of pesticides, etc were priced in (Food and Agriculture Organization, 2014). Also, $76 \%$ of the calories grown by the industrial food system are wasted, and only $5 \%$ of artificial fertilizers contribute to actual edible plant parts the rest is wasted. Production of synthetic nitrogen fertilizers consumes $2 \%$ of the world's energy and in 2007 , generated 465 million tonnes of $\mathrm{CO}_{2}$ emissions (Ellen MacArthur Foundation, 2018). Moreover, roughly onethird of the food produced in the world for human consumption every year approximately 1.3 billion tonnes get lost or wasted (Food and Agriculture Organization, 2011).

\section{Nutrient Flows are Disrupted}

The current food system is linear and it does not cycle nutrients effectively. As crops are harvested, nutrients and organic matter are removed. Excessive use of pesticides and synthetic fertilizers can also lead to increased toxicity levels, reducing the soil's capacity to support growth. The nutrients are extracted from the biosphere as harvested food and become concentrated in cities. They are damaging ecosystem where they are discharged as food waste and sewage sludge rather than being beneficially looped back to the soil. Concentration and discharge of nutrients in wastewater systems can also contribute to the dead zone problem. Among the EU, $70 \%$ of the phosphorus in sewage sludge and biodegradable solid waste is not recovered and in Bangkok, an estimated $90 \%$ of the 26,000 tonnes of nitrogen that enters the city each year is lost, primarily through the city's waterways (Ellen MacArthur Foundation, 2018).

\section{Opportunities of Circular Economy in Agriculture}

The world's population is anticipated to grow to 10 billion by 2050 . Resource-intensive farming systems that have caused massive deforestation, water scarcities, soil depletion, and high levels of greenhouse gas emissions cannot deliver sustainable food and agricultural production (Food and Agriculture Organization, 2017). If our society continues in its current patterns of production and consumption, we will soon face a twin environmental crisis of resource scarcity and waste overload.

The continuing reserve reduction of natural resources without replenishment runs the risk of ecological collapse (Kyriakopoulos et al., 2019). A major transformation of agricultural systems, rural economies, and natural resource management are needed if we are to solve the multifaceted problems caused by linear model and business-as-usual won't help to achieve a sustainable system. The circular agriculture can help to address the issue to a great extent. Some opportunities that can be addressed once we move from linear to a circular model of the economy are as follows:

\section{Resource Recovery from Urban Waste}

Resources are extracted, processed into materials and products, consumed and then wasted away that creates the paradox where people continue to deplete virgin resources while adding to waste management issues (Velenturf and Purnell, 2017). Municipal Solid Waste (MSW) in Nepal is 
composed of $56 \%$ organic waste, $16 \%$ plastics, and $16 \%$ paper and paper products. This shows the maximum potential of resource recovery by reusing and recycling materials, with only about $10 \%$ going to final disposal if resource recovery is maximized (Asian Development Bank, 2013). Cities are not only hungry but they are also thirsty (Van Rooijen et al., 2005). The urban city is absorbing freshwater from its periphery and discharging wastewater. Waste-water, if treated has a high potential to support ecosystem services and food production in waterscarce regions. Urban waste offers scalable opportunities to transform waste sources into valuable assets for use in agriculture. This is will address Sustainable Development Goals (SDG) framed by UNDP. For example, water reuse (SDG 6), waste recycling and reuse (SDG 12) help to restore degraded soils (SDG 15) which further helps to address sustainable agriculture and food security (SDG 2) and resilient cities (SDG 11) (Ellen MacArthur Foundation, 2017). These opportunities that would otherwise be irreversibly lost also allow for cost savings in the sanitation sector; for example, composting depending on scale reduces solid waste volumes and transport costs enhancing the lifetime of landfills with less green-house gas (GHG) emissions. Furthermore, by increasing amounts of bio-degradable resources through anaerobic digestion or composting back into the soil, a circular economy approach will reduce the need for chemical fertilizers and soil amendments.
Similarly, locally available wastes can find the market in a circular economy scenario. For example, a human hair is one of the highest nitrogen-containing $(\sim 16 \%)$ of organic material in nature. Also, human hair contains sulphur, carbon, and 20 other elements essential for plants (Zheljazkov, 2005). Similar to human hair, there are poultry feathers and animal hair. The hydrolyzed solution hair, which mainly consists of amino acids, some fatty acids, and nucleotides, can be used as a liquid fertilizer. Experiments using this hydrolyzate as foliar spray show enhancement of the chlorophyll content as well as biomass in spinach and wheat plants (Yadav et al., 1995). Thus prepared plant booster can fetch a high price in countries that value indoor farming.

\section{Agricultural Waste}

Resources like crop residues and manures can remain valorized to produce energy and bio-chemicals for the wider bio-economy, thereby not being 'circularised' (Oldfield et al., 2016). It is generally assumed that narrowing (using few resources), slowing (continuous use over a long time) or closing (recycling) resource reduces environmental impact but sometimes, there are tradeoffs where some environmental impacts are reduced but others are increased. And one needs to carefully choose among alternative pathways to minimize the impact.

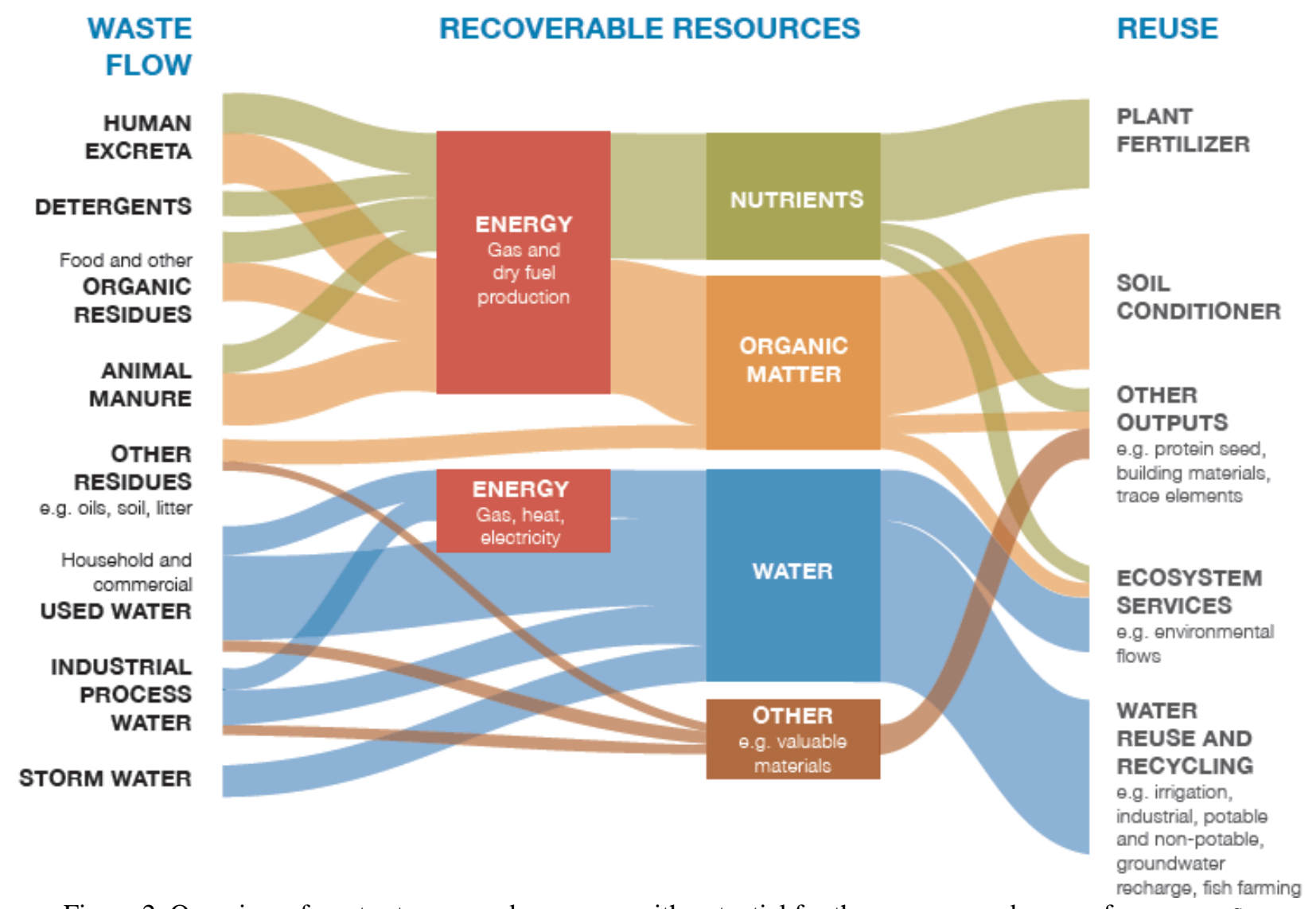

Figure 2. Overview of waste streams and resources with potential for the recovery and reuse of resources Source: Anderson et al., 2006 
Table 1. Possible commercial products from wasted resources

\begin{tabular}{|c|c|c|}
\hline Commercial product & Possible raw materials & Possible processes \\
\hline Compost, Vermicompost & $\begin{array}{l}\text { Manure, crop residues, food waste, } \\
\text { etc. }\end{array}$ & Composting \\
\hline $\begin{array}{l}\text { Liquid \& Solid of separated slurry or } \\
\text { digestate }\end{array}$ & Slurry/ digestate & $\begin{array}{l}\text { Anaerobic digestion (Solid-liquid } \\
\text { separation) }\end{array}$ \\
\hline $\begin{array}{l}\text { Digestate from manure, herbaceous } \\
\text { material \& food waste }\end{array}$ & Manure, food waste, corn stover, etc. & Anaerobic digestion \\
\hline $\begin{array}{l}\text { Nutrient-rich fertilizer from the } \\
\text { liquid fraction of digestate }\end{array}$ & $\begin{array}{l}\text { Food waste, animal manure, organic } \\
\text { sludge }\end{array}$ & Anaerobic digestion \& evaporation \\
\hline $\begin{array}{l}\text { Ammonium nitrate/sulphate from } \\
\text { scrubbed ammonia }\end{array}$ & $\begin{array}{l}\text { The liquid phase of digestate or } \\
\text { manure }\end{array}$ & $\begin{array}{l}\text { Ammonium desorption, ammonium } \\
\text { nitrate/sulphate precipitation }\end{array}$ \\
\hline Bone meal fertiliser & Animal bones & \\
\hline Feather fertilizer & Poultry feathers & \\
\hline Biochar & Biomass & Pyrolysis \\
\hline Struvite & $\begin{array}{l}\text { Wastewater, the liquid phase of } \\
\text { digestate or manure }\end{array}$ & Struvite crystallization \\
\hline Plant-based fertilizer & Alfa-alfa, corn, etc. & $\begin{array}{l}\text { Composting/fermentation, } \\
\text { Pulverization }\end{array}$ \\
\hline
\end{tabular}

Source: (Berkum and Dengerink, 2019)

Regarding food waste, it is necessary to differentiate between avoidable and unavoidable food waste. The priority should be such that avoidable food wastes need to be prevented first, followed by the treatment of generated waste through recycling into animal feed and composting (Papargyropoulou et al., 2014). Cities constitute vast sinks of food wastes including valuable crop nutrients and organic matter. On the other end, rural, peri-urban, or urban farmers struggle with depleted soils to feed the growing urban population. It is the loss of valuable finite resources and also causes environmental pollution and the production of avoidable GHG. Halving the current rate of food wastage would support waste management and reduce the emission of GHG by 22-28\% (World Economic Forum, 2016). Some unavoidable food waste can be converted into high-value protein products and feeds from utilizing novel black soldier fly larvae to circulate nutrients back to the economy. The larvae of the black soldier fly (BSF) can convert low-value organic resources into a high-quality protein source thereby increasing both the productivity and the efficiency of the food chain. Capturing all the nutrients from the current stocks of cattle, chicken, pig, and sheep manure would incredibly yield 345 million tonnes of $\mathrm{N}, \mathrm{P}$, $\mathrm{K}$ annually which is more than twice the world's current consumption (Ellen MacArthur Foundation, 2013).

\section{Possibility of Digitalization}

The digitalization in agriculture allows us to measure, track, and locate food and other agricultural commodities with more precision allowing better management and allocation of resources. By leveraging the technology we can effectively allow farmers to share or rent their agricultural equipment with other farmers thereby stimulating sharing economy which is a part of a wider circular economy. For example, JFarm in India is connecting small and marginal farmers with tractor and equipment owners through its Farmer-2-Farmer platform where farmers can explore and book nearby equipment through JFarm Services mobile app (TAFE, 2020). This way, it helps to maximize the utilization rate of agricultural assets by making possible shared use or access or ownership.

\section{Barriers for Circular Agriculture}

The transition from the linear approach to circular agriculture is not that straightforward. For the transition, proper identification of the intervention is essential to close the loop by studying the existing system. But, in case of Nepal, we do not have adequate understanding about the materials used, the source of those materials and their sustainable replacement in the academic circle. This improper understanding of the circular economy may act as an important barrier for implementation (Rizos et al., 2015). Research and investigation on the aspects of circular agriculture in Nepal is almost nil. Additionally, the government and other stakeholders are yet to realize the need of transition towards circular agriculture, which means there are neither policies to drive towards circular agriculture nor the understanding essential for that. In addition to this, the adaptation of circular agriculture approach requires investment. But, even in developed countries, finance has been recognized as a key barrier especially for the small and medium enterprises, for the development and implementation of innovative products under circular economy (Rizos et al., 2015). Korhonen et al. (2018) had discussed the concepts and limitations of the agricultural circular economy. Comparing the similarities and differences in the concepts of a circular economy, a green economy, and a bio-economy, they found that the assumptions and strategies for the three were different but that these concepts shared common economic, environmental, and social goals. Wang B et al. (2016) verified that the utilization efficiency of traditional agricultural waste recycling was low. They concluded that technological innovations, people's motivation, costs, and environmental policies were the factors influencing agricultural waste recycling. He K et al. (2016) divided the factors that affected farmers' willingness to recycle waste into economic and non-economic factors, such as people's age, attitude, family income, and income sources. They found that setting compensation in a range of $1.08 \%$ to $0.31 \%$ of the average annual household income would encourage farmers to recycle agricultural waste. There is an urgent need to come up with a solution to alleviate the contradiction among resources, environment, and economic development mode (Liu et al., 2018). 
But the circular economy is an entirely latest concept to the Nepalese agricultural sector. Along with this, the volume of literature relating circular economy to agriculture is increasing particularly within China and European Union (Michelini et al., 2017; Pattanaro and Gente, 2017), how the topic can be appropriate to countries like Nepal are largely limited.

Nepalese agricultural economy is predominated by the linear approach and it needs a transition towards a more sustainable approach. There is huge potential to make a transition of this sector. But, these transitions are stuck by lack of comprehensive study on the hospitality sector from circular agriculture perspectives, lack of awareness in the related stakeholders about the circular agriculture perspectives. Additionally, there could be a financial hindrance in various forms. If we overcome these challenges and make the transition to a circular economy it will help to reunite environmental, social and economic perspectives in agriculture and support in achieving sustainable development goals. Furthermore, after the implementation of a circular economy model, they should be monitored regularly by developing proper sets of indicators (Aryal, 2020).

\section{Linkages of Circular Agriculture Approach to Global Challenges \\ A Climate change and water scarcity}

- Shows opportunities for reducing the emission of greenhouse gases by closing loops of material flow

- Helps in identifying opportunities to recover and reuse water streams to reduce water pressures

B Urbanisation

- Shows opportunities for creating urban food systems where material and nutrient cycles are shortened and used more efficiently (e.g. urban farming, vertical farming)

- Possibilities to recycle urban food waste and nutrients

C Productivity, hunger, and malnutrition

- Shows opportunities for using underutilized resources at the farm level and benefitting from waste recycling elsewhere in the supply chain

- Possibilities to improve resource efficiency for increasing productivity and improving livelihoods

D Deforestation and decreasing biodiversity

- Shows opportunities for food production systems reducing environmental pressure

- Possibilities to reduce pressures to land conversion by optimizing the use of existing resources

Source: Berkum and Dengerink, 2019

\section{Conclusion and Recommendations}

The circular economy is about decoupling economic growth from unsustainable use of scarce resources aiming at maximizing resource efficiency and minimizing waste production. It provides a clear way to ease the tension between economic development and ecological collapse; addresses the environmental degradation and resource scarcity problem. The circular economy framework provides an opportunity for concerned stakeholders to take initiative in different parts of the circle to promote circularity. The circular economy is clear that the circular economy helps to maintain and increase the resilience and ability of our environment to provide us with ecological services by reducing pressures and demands upon it. The approaches taken in different parts of the world to address the circular economy within the agriculture sector can be tailored-made integrating local socio-cultural habits and local resources to fit within our context. Nepal has huge potential to take benefit, both social and monetary benefits on transition from exhaustive linear model to more sustainable circular economy. All relevant actors should embrace circular economy to unleash the potential benefits offered by it. Government should promote economic incentives through policies to stimulate the behaviours of stakeholders. New measures like environmental taxes, insurance for liability resulting from environmental damage, cap and trade system and environmental labelling can be explored to promote transition of current linear and extractive model to a sustainable and circular one. While $100 \%$ circular economy is a utopian society to all of us, its importance needs to be realized and we need a paradigm shift in thinking to address it. Lastly, we as consumers need to make more conscious choices to promote sustainable practices so that firms, in turn, produce more conscious and environmentally friendly products.

\section{References}

Andersson K, Rosemarin A, Lamizana B, Kvarnström E, McConville J, Seidu R, Dickin S, Trimmer C. 2016. Sanitation, Wastewater Management and Sustainability: From Waste Disposal to Resource Recovery. Nairobi and Stockholm: United Nations Environment Programme and Stockholm Environment Institute. ISBN: 978-92-807-3488-1.

Aryal C. 2020. Exploring Circularity: A Review to Assess the Opportunities and Challenges to Close Loop in Nepali Tourism Industry. Journal of Tourism \& Adventure, 3(1): 142-158. DOI: 10.3126/jota.v3i1.31362.

Asian Development Bank. 2013. Solid waste management in Nepal: Current status and policy recommendations. Manila, Phillipines: Asian Development Bank. ISBN: 978-92-9254233-7 (Online) ISBN: 978-92-9254-232-0 (Print). Available from: http://hdl.handle.net/11540/817 [Accessed 09 August 2020].

Berkum SV, Dengerink J. 2019. Transition to sustainable food systems: The Dutch circular approach providing solutions to global challenges. Hague: Wageningen Economic Research. Report number: 2019-082. DOI: 10.18174/495586.

Cordell D, White S. 2014. Life's Bottleneck: Sustaining the world's phosphorus for a food secure future. Annual Review of Environment and Resources, 39(1): 161-188. DOI: 10.1146/annurev-environ-010213-113300.

Ellen MacArthur Foundation. 2018. Cities and the circular economy for food. UK: Ellen MacArthur Foundation. Available from: https://www.ellenmacarthurfoundation.org/assets/downloads /Cities-and-Circular-Economy-for-Food_280119.pdf [Accessed 13 November 2020]

Ellen MacArthur Foundation. 2017. Concept- What is circular economy? A framework for an economy that is restorative and regenerative by design. UK: Ellen MacArthur Foundation. Available from: https://www.ellenmacart hurfoundation.org/circular-economy/concept [Accessed 24 March 2020]

Ellen MacArthur Foundation. 2014. Towards the circular economy: Accelerating the scale up across global supply chains. UK: Ellen MacArthur Foundation. Available from: https://www.ellenmacarthurfoundation.org/publications/tow ards-the-circular-economy-vol-3-accelerating-the-scale-upacross-global-supply-chains [Accessed 13 November 2020] 
Ellen MacArthur Foundation. 2013. Towards the circular economy- Opportunities for the consumer goods sector. UK: Ellen MacArthur Foundation. Available from: https://www.ellenmacarthurfoundation.org/publications/tow ards-the-circular-economy-vol-2-opportunities-for-theconsumer-goods-sector [Accessed 13 November 2020]

Ellen MacArthur Foundation. 2017. Urban Biocycles. UK: Ellen MacArthur Foundation. Available from: www.ellenmacart hurfoundation.org/publications/urban-biocyles [Accessed 24 March 10 2020]

FAO, IFAD, and WFP. 2015. The State of Food Insecurity in the World 2015: Meeting the 2015 International Hunger Targets: Taking Stock of Uneven Progress. Rome: FAO, Advances in Nutrition, 6(5): 623-624. DOI: https://doi.org/10.3945/ an.115.009936.

Food and Agriculture Organization. 2011. Global Food Losses and Food Waste - Extent, Causes and Prevention. Rome: FAO. Available from: http://www.fao.org/3/mb060e/ mb060e00.htm [Accessed 12 November 2020]

Food and Agriculture Organization. 2014. Food wastage footprint, Full cost accounting. Rome: FAO. Available from: http://www.fao.org/3/a-i3991e.pdf [Accessed 13 November 2020]

Food and Agriculture Organization. 2017. The future of food and agriculture- Trends and challenges. Rome: FAO. Available from: http://www.fao.org/publications/fofa/en/ [Accessed 13 November 2020]

Frodermann L. 2018. Exploratory Study on Circular Economy Approaches: A Comparative Analysis of Theory and Practice. Wiesbaden:VS Verlag für Sozialwissenschaften. DOI: 10.1007/978-3-658-21949-9.

Gauchan, D. 2015. Thematic Report on Agriculture Sector. Nature Conservation National Strategic Framework for Sustainable Development. Kathmandu: National Planning Commission and International Union for Conservation of Nature (IUCN). Available from: https://www.iucn.org/sites/ dev/files/content/documents/english_nature_conservation_n ational_strategic_framework_for_sustainable_development. pdf [Accessed 13 November 2020]

He K, Zhang J, Zeng Y, Zhang L. 2016. Households' Willingness to Accept Compensation for Agricultural Waste Recycling: Taking Biogas Production from Livestock Manure Waste in Hubei, P.R. China as An Example. Journal of Cleaner Production, 131: 410-420. DOI: https://doi.org/10.1016/ j.jclepro.2016.05.009

Junjie CAO, Ming LI, Shuguo LI. 2011. Development Strategy Research of Modern Eco-Agriculture on the Basis of Constructing the Rural Circular Economy - For the Example of Shandong Province. Energy Procedia 5: 2504-2508. DOI: https://doi.org/10.1016/j.egypro.2011.03.430

Korhonen J, Honkasalo A, Seppälä J. 2018. Circular Economy: The Concept and Its Limitations. Ecological Economics, 143: 37-46. DOI: 10.1016/j.ecolecon.2017.06.041

Kyriakopoulos G L, Kapsalis V C, Aravossis K G, Zamparas M and Mitsikas A. 2019. Evaluating Circular Economy under a Multi- Parametric Approach: A Technological Review. Sustainability. DOI: https://doi.org/10.3390/su11216139

Liu J, Feng Y, Zhu Q, Sarkis J. 2018. Green Supply Chain Management and the Circular Economy. International Journal of Physical Distribution and Logistics Management. 48: 794-817. DOI:10.1108/IJPDLM-01-2017-0049

Michelini G, Moraes RN, Cunha RN, Costa JMH and Aldo R. 2017. From Linear to Circular Economy: PSS Conducting the Transition. Procedia CIRP, 64: 2-6. DOI: https://doi.org/10.1016/j.procir.2017.03.012
Ministry of Finance. 2020. Budget speech for FY 2077/78. Kathmandu: Ministry of Finance, Government of Nepal. Available from: https://mof.gov.np/en/archive-documents/ budget-speech-17.html [Accessed 13 November 2020]

Ministry of Finance, GoN. 2018. Economic Survey 2017/18. Kathmandu: Ministry of Finance, Government of Nepal. Available from: https://mof.gov.np/en/archive-documents/ economic-survey-21.html [Accessed 13 November 2020]

MoAD (Ministry of Agricultural Development). 2015. Statistical Information in Nepalese Agriculture (2014/15). Kathmandu: Ministry of Agricultural Development. Available from: https://nepalindata.com/resource/statistical-informationnepalese-agriculture-201415-2071072/ [Accessed November 2020]

NEF. 2019. Mainstreaming Circular Economy in Nepal. In Himalayan Circular Economy Forum (HiCEF) Dialogue, Nepal Economic Forum, Kathmandu Nepal. Available from: https://issuu.com/nepaleconomicforum/docs/nefport_402020-web [Accessed 13 November 2020]

Netherlands government. 2016. A Circular Economy in the Netherlands by 2050: Government-wide Programme for a Circular Economy. Available from: https://theconversation.com/ the-planned-national-waste-policy-wont-deliver-a-trulycircular-economy-103908 [Accessed 13 November 2020]

Oldfield T, Ward S, Holden N. 2016. The 'circular economy' applied to the agriculture (livestock production) sectordiscussion paper. Brussels: Workshop on the Sustainability of the EU's Livestock Production Systems. Available from: https://www.researchgate.net/publication/328638161_The_'c ircular_economy'_applied_to_the_agriculture_livestock_pro duction_sector_-_discussion_paper [Accessed 13 November 2020]

Panta H. 2018. Supply chain of subsidized chemical fertilizers in Nepal. Journal of Institute of Agriculture and Animal Science. 35(1): 9-20. DOI: https://doi.org/10.3126/ jiaas.v35i1.22509

Papargyropoulou E, Lozano R, Steinberger J K, Wright N, Bin Ujang Z. 2014. The food waste hierarchy as a framework for the management of food surplus and food waste. Journal of Cleaner Production. DOI: https://doi.org/10.1016/ j.jclepro.2014.04.020

Parajuly K. 2019. Circular Economy and Waste Management in Nepal. International Youth Conference on Science, Technology and Innovation, 270-272.

Rizos V, Behrens A, Kafyeke T, Hirschnitz-garbers M and Ioannou A. 2015. The Circular Economy : Barriers and Opportunities for SMEs, 412. ISBN: 978-94-6138-479-9.

Secco C, da Luz LM, Pinheiro E, Puglieri FN, Piekarski CM, de Francisco AC, Freire FMCS 2020. Circular economy in the pig farming chain: proposing a model for measurement. $\mathrm{J}$ Clean Prod.

TAFE. 2020. Available from: https://www.tafe.com/ JFarmServices/ [Accessed 13 March 2020]

Tonini D, Saveyn HG, Huygens D. 2019. Environmental and health co-benefits for advanced phosphorus recovery. Nature sustainability. DOI: 10.1038/s41893-019-0416-x

Van Rooijen JD, Turral H, Biggs TW. 2005. Sponge city: Water balance of mega-city water use and wastewater use in Hyderbad, India. Irrigation and Drainage. DOI: 10.1002/ird. 188

Velenturf AP, Purnell P. 2017. Resource Recovery from Waste: Restoring the Balance between Resource Scarcity and Waste Overload. Sustainability, 9(9), 1603. DOI: https://doi.org/10.3390/su9091603 
Wang B, Dong F, Chen M, Zhu J, Tan J, Fu X, Wang Y and Chen S. 2016. Advances in Recycling and Utilization of Agricultural Wastes in China: Based on Environmental Risk, Crucial Pathways, Influencing Factors, Policy Mechanism. Procedia Environmental Sciences. 31, 12-17. DOI: 10.1016/j.proenv.2016.02.002

World Economic Forum. 2016. The global risks report. Geneva: WEF. Available from: https://www.weforum.org/reports/theglobal-risks-report-2016 [Accessed 13 November 2020]
Yadav KR, Sharma RK, Yadav MP, Kothari RM. 1995. Human Hair Waste: An Environmental Problem Converted into an Eco-friendly Plant tonic. Fresenius Environmental Bulletin, 4(8): 491-496.

Zheljazkov VD. 2005. Assessment of Wool Waste and Hair Waste as Soil Amendment and Nutrient Source. Journal of Environmental Quality, 34 (6). DOI: 10.2134/jeq2004.0332. 